University of Nebraska - Lincoln

DigitalCommons@University of Nebraska - Lincoln

Agronomy \& Horticulture -- Faculty Publications

Agronomy and Horticulture Department

2006

\title{
Soybean row spacing and weed emergence time influence weed competitiveness and competitive indices
}

\author{
Shawn M. Hock \\ University of Nebraska-Lincoln \\ Stevan Z. Knezevic \\ University of Nebraska-Lincoln, sknezevic2@unl.edu \\ Alex Martin \\ University of Nebraska-Lincoln, amartin2@unl.edu \\ John L. Lindquist \\ University of Nebraska-Lincoln, jlindquist1@unl.edu
}

Follow this and additional works at: https://digitalcommons.unl.edu/agronomyfacpub

Part of the Plant Sciences Commons

Hock, Shawn M.; Knezevic, Stevan Z.; Martin, Alex; and Lindquist, John L., "Soybean row spacing and weed emergence time influence weed competitiveness and competitive indices" (2006). Agronomy \& Horticulture -- Faculty Publications. 375.

https://digitalcommons.unl.edu/agronomyfacpub/375

This Article is brought to you for free and open access by the Agronomy and Horticulture Department at DigitalCommons@University of Nebraska - Lincoln. It has been accepted for inclusion in Agronomy \& Horticulture -Faculty Publications by an authorized administrator of DigitalCommons@University of Nebraska - Lincoln. 


\section{Soybean row spacing and weed emergence time influence weed competitiveness and competitive indices}

Shawn M. Hock

Department of Agronomy and Horticulture, University of Nebraska, Lincoln, NE 68583-0915

\section{Stevan Z. Knezevic}

Corresponding author. Haskell Agricultural Laboratory, University of Nebraska, 57905866 Road, Concord, NE 68728-2828;

sknezevic2@unl.edu

\section{Alex R. Martin}

John L. Lindquist

Department of Agronomy and Horticulture, University of Nebraska, Lincoln, NE 68583-0915

\begin{abstract}
Weed competitiveness can be quantified with the concept of competitive index (CI), a relative scale of weed competitiveness. Field studies were conducted in 2002 and 2003 in northeastern and southeastern Nebraska to evaluate the influence of soybean row spacing and relative weed emergence time on the competitiveness of major weed species in soybean. Ten weed species were seeded in soybean spaced 19 and $76 \mathrm{~cm}$ apart at the planting, emergence, and first trifoliate leaf stages of soybean. Total weed dry matter (TDM), weed plant volume, and percent soybean yield loss were arbitrarily selected as a base for determining the CI for each weed species. Soybean yield loss was the least variable parameter used to quantify weed competitiveness and rank their CIs. In general, weeds grown with soybean planted in 19-cm rows produced less TDM, plant volume, and reduced soybean yield less than weed species grown in 76- $\mathrm{cm}$ rows. Later-emerging weeds produced less TDM, plant volume, and reduced soybean yield less than the early-emerging ones. In general, broadleaf species were more competitive than grass weed species. Common sunflower was the most competitive weed species in this study.
\end{abstract}

Nomenclature: Common sunflower, Helianthus annuиs L. HELAN; soybean, Glycine $\max (\mathrm{L}$.$) Merr. 'Agripro 2502', 'Agripro 2703'.$

Key words: Competitive index, integrated weed management, plant volume, weed competition.
Weed populations in agricultural systems often consist of a broad complex of species and densities making management decisions complicated. A producer faced with a single weed species in his crop can generally make an economically based decision fairly efficiently (Forcella et al. 1996). However, in most cases producers are faced with a multi-species complex of weeds, different relative emergence times, variable weed densities, and site-specific environmental conditions (Evans et al. 2003; Knezevic et al. 1997, 2002, 2003). All these factors complicate the decision-making process, thereby necessitating computerized systems to integrate system information.

A number of computer programs have been developed over the past two decades to assist practitioners in making weed management decisions (Martin et al. 1997). Decision support systems (DSSs) are designed to help growers make weed management decisions that are economically and biologically justified. For these reasons, some in the weed science discipline have conducted research to contribute information toward construction and calibration of various DSSs (Gunther et al. 1993; Medd and Pandey 1993; Schweizer et al. 1994; Stigliani and Resina 1993; Wilkerson et al. 1991).

Some DSSs use the concept of competitive indices (CIs) for ranking weed species competitiveness. Coble and Mortensen (1992) proposed the CI indexing system and suggested that it measured relative weed competitiveness, with larger CI values indicating more competitive weeds. Such a ranking system of weed competitiveness is used in WeedSOFT, a DSS developed in Nebraska (Neeser et al. 2004). WeedSOFT calculates crop yield loss using several input variables and a set of yield loss functions. Input variables are provided by the user and include information about the crop species, crop growth stage, and density and growth stage of over 40 weed species. Crop yield loss due to each weed species is calculated by using its CI value. WeedSOFT uses a modifier to adjust the CI values to account for crop row spacing and weed and crop growth stages (Neeser et al. 2004). Many CI values in WeedSOFT are based on expert opinion or experimental data or both derived from singlespecies crop-weed competition studies. However, expert opinions can differ, while results of many single-weed cropweed interference studies can be variable among years and locations (Bauer et al. 1991; Chikoye et al. 1995; Cousens et al. 1988; Knezevic et al. 1995, 1997; Lindquist et al. 1999; Lotz et al. 1996). Therefore a total of ten common midwestern U.S. weed species were seeded in soybean with the primary objective of describing their growth as influenced by crop row spacing and weed emergence timing. The secondary objective was to determine the CI for each of the weed species and rank them according to their competitiveness.

\section{Materials and Methods}

Field experiments were conducted in 2002 and 2003 at the University of Nebraska Haskell Agricultural Laboratory in Concord, NE (lat $42.37^{\circ} \mathrm{N}$, long $96.97^{\circ} \mathrm{W}$ ) and in 2003 at the University of Nebraska Agricultural Research Farm in Lincoln, NE (lat $40.82^{\circ} \mathrm{N}$, long $96.68^{\circ} \mathrm{W}$ ) for a total of 3 site yr. Concord and Lincoln are located in northeastern and southeastern Nebraska, respectively, and are approximately $190 \mathrm{~km}$ apart. Soil types were Kennebec series silty clay loam (fine-silty mixed, mesic Cumulic Hapludolls) at Concord, and Sharpsburg series silty clay loam (fine, montmorillonitic mesic Typic Argiudolls) at Lincoln. 


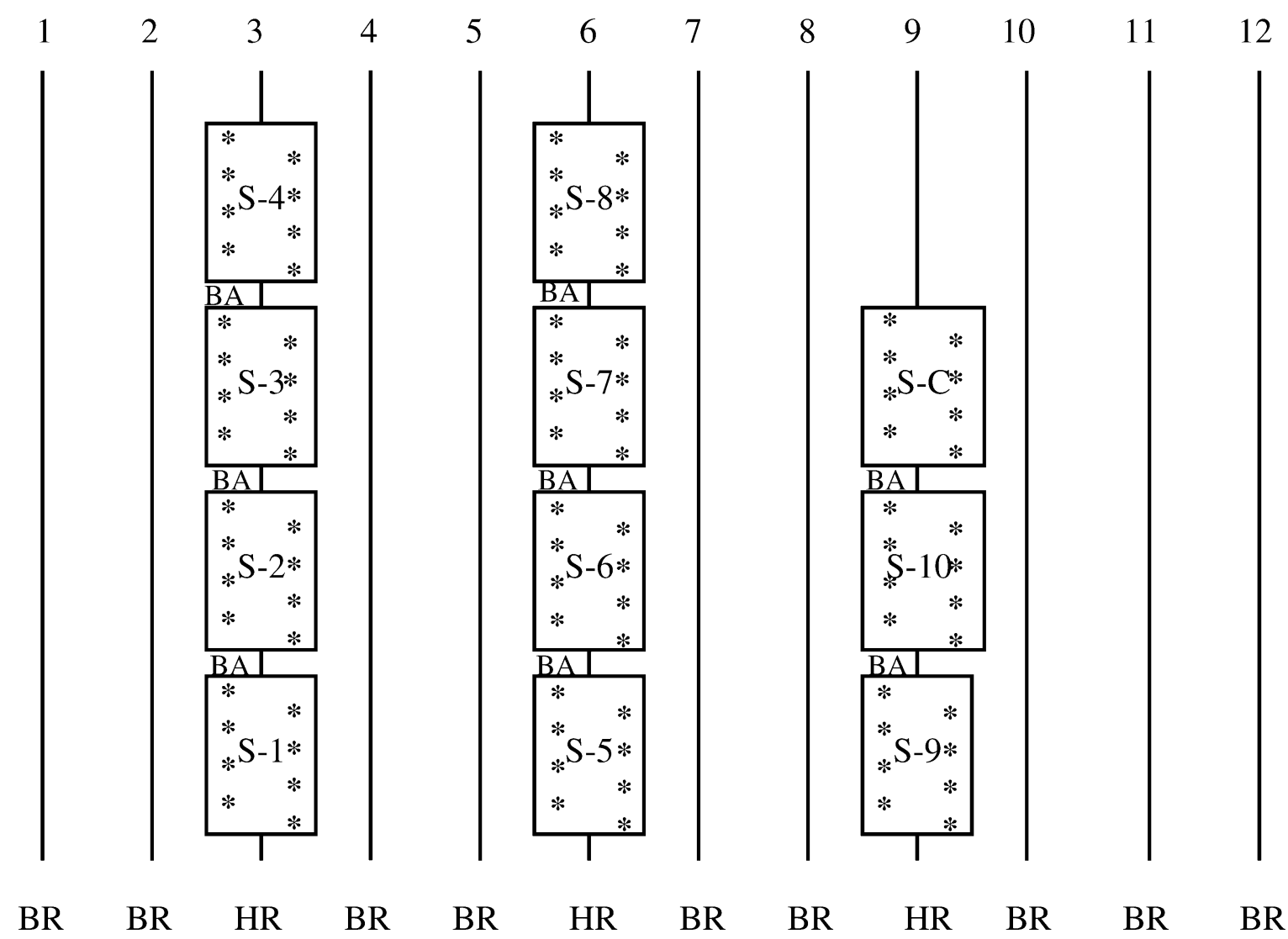

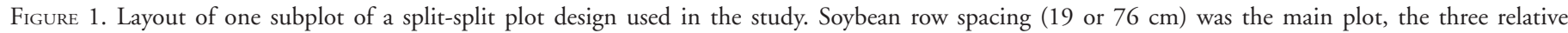

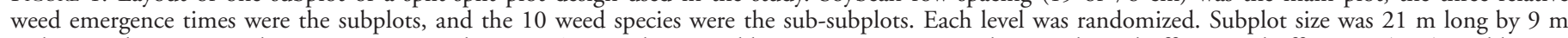

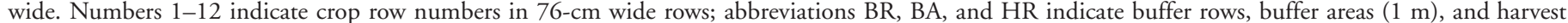

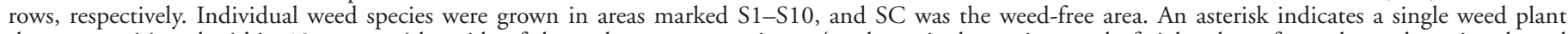

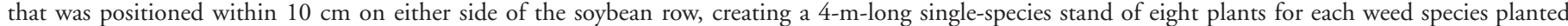
$1 \mathrm{~m}$ apart. The same layout was used in the $19-\mathrm{cm}$ row spacing, but the subplot had a total of 48 rows to cover the same land area.

For each year and location, primary tillage consisted of spring disking followed by field cultivation before soybean planting. The previous crop was grain sorghum [Sorghum bicolor (L.) Moench] at Lincoln and corn (Zea mays L.) at Concord for each year. Glyphosate-tolerant soybean varieties, 'Agripro 2502' and 'Agripro 2703', were planted in Concord and Lincoln, respectively, at a density of 407,000 seeds ha ${ }^{-1}$ in 19- and 76-cm rows using a John Deere drill. Soybean was planted on May 31, 2002, and June 5, 2003, at Concord and on May 29, 2003, at Lincoln.

Experiments were established in a factorial arrangement of treatments in a split-split plot design with four replicates. Soybean row spacing $(19$ or $76 \mathrm{~cm}$ ) was the main plot completely randomized, the three relative weed emergence times were the subplots randomized within the main plots, and the 10 weed species were the sub-subplots randomized within the subplots (Figure 1). The main plot was $75 \mathrm{~m}$ long with twelve 76- and forty-eight 19-cm-wide rows running the length of the plot. The three subplots were established by seeding weeds at soybean planting, emergence (VE), and first trifoliate leaf (V1) stages. The six broadleaf and four grass weed species included common cocklebur (Xanthium strumarium L. XANST), common sunflower (Helianthus annuus L. HELAN), common waterhemp (Amaranthus rudis Sauer AMATA), giant ragweed (Ambrosia trifida L. AMBTR), redroot pigweed (Amaranthus retroflexus L. AMA$\mathrm{RE}$ ), velvetleaf (Abutilon theophrasti Medic. ABUTH), barn- yardgrass [Echinochloa crus-galli (L.) Beauv. ECHCG], fall panicum [Panicum dichotomiflorum (L.) Michx. PANDI], giant foxtail (Setaria faberi Herrm. SETFA), and yellow foxtail [Setaria glauca (L.) Beauv. SETLU]. The ten weed species were established at Concord in both years; however, giant ragweed had sporadic establishment and thus soybean yield loss data are not presented. At Lincoln, fall panicum was the only weed to have poor emergence; thus data are not presented. Seeds of a single weed species were hand planted, alternating $10 \mathrm{~cm}$ on either side of the soybean row spaced $0.5 \mathrm{~m}$ apart, creating a 4-m-long single-species stand of eight plants for each weed species (Figure 1). Soybean growth stages were determined as described by Ritchie et al. (1993). Weed emergence dates were recorded at the time of approximate $50 \%$ weed emergence (Table 1). For example, the weed emergence date was recorded when four out of eight weed plants had emerged in a sub-subplot. Weeds were thinned by hand to obtain desired density of 1 plant per $0.5 \mathrm{~m}$ of row weekly beginning at soybean V1 stage. Undesirable species were removed by hand or sprayed with glyphosate at a labeled rate as needed. Plastic jugs were temporarily placed over desired weeds to protect them from glyphosate drift.

Plant height was measured from the soil surface to the highest free-standing point of one randomly selected plant in each sub-subplot. Canopy diameter was measured at its widest point. Weed plant height and canopy diameter were 
TABLE 1. Weed planting and emergence dates, and soybean leaf stages at the time of weed emergence for each weed cohort in 2002 and 2003.

\begin{tabular}{|c|c|c|c|c|c|c|c|c|c|}
\hline \multirow[b]{3}{*}{ Cohort } & \multicolumn{3}{|c|}{ Planting date } & \multicolumn{3}{|c|}{ Emergence date } & \multicolumn{3}{|c|}{ Soybean leaf stage } \\
\hline & \multicolumn{2}{|c|}{ Concord } & \multirow{2}{*}{$\begin{array}{c}\text { Lincoln } \\
2003\end{array}$} & \multicolumn{2}{|c|}{ Concord } & \multirow{2}{*}{$\begin{array}{c}\text { Lincoln } \\
2003\end{array}$} & \multicolumn{2}{|c|}{ Concord } & \multirow{2}{*}{$\begin{array}{c}\text { Lincoln } \\
2003\end{array}$} \\
\hline & 2002 & 2003 & & 2002 & 2003 & & 2002 & 2003 & \\
\hline 1 & May 31 & June 5 & May 29 & June 10 & June 16 & June 10 & VE & VE & VE \\
\hline 2 & June 10 & June 13 & June 7 & June 19 & June 25 & June 17 & $\mathrm{~V} 1$ & $\mathrm{~V} 1$ & $\mathrm{~V} 1$ \\
\hline
\end{tabular}

a Abbreviations: VE, emergence; V1, first trifoliate leaf.

measured biweekly until physiological maturity. Weed volume was defined and presented as the point of maximum cylindrical volume for each respective weed species and was calculated using Equation 1:

$$
\mathrm{V}=\pi \times r^{2} \times h
$$

where $\mathrm{V}$ is weed volume $\left(\mathrm{cm}^{3}\right), \pi$ is the ratio between the circumference and the diameter of any given circle equaling $3.14159, r$ is the radius of the weed at its widest point, and $h$ is weed height. Weed aboveground biomass (TDM) was harvested by hand over a week-long period as the weed species reached their respective physiological maturity. Samples were dried at $70 \mathrm{C}$ to a constant mass and weighed.

Soybean plants were hand harvested in each sub-subplot at physiological maturity from a 4-m length of one row in $76-\mathrm{cm}$ rows or four rows in $19-\mathrm{cm}$ rows. There were two weed-free buffers, 2- and 1-m long, between each subplot and sub-subplots, respectively, and weed-free buffers of 1.5 $\mathrm{m}$ between sub-subplots (Figure 1). Weed-free buffers successfully prevented competition between plants of neighboring sub-subplots. Weed-free yield was harvested from a single soybean row in 76-cm rows and from four rows in 19-cm rows, each $4 \mathrm{~m}$ long. Soybean plants were counted and threshed to separate grain. Seeds were then dried at 70 $\mathrm{C}$ to a constant mass and weighed. Yield loss was calculated by relating the weed-free yield to the yield from each subsubplot.

\section{Data Analysis}

Analyses of variance was performed using PROC MIXED procedure in SAS (1999) to test significance $(\mathrm{P}<0.05)$ of year, location, soybean row spacing, weed emergence time, weed species, replications, and their interactions with weed TDM, weed volume, and soybean yield loss response variables.

Values of CI were calculated for each weed species based on weed TDM, weed volume, or soybean yield loss using Equation 2:

$$
\mathrm{CI}_{x}=\left(A_{x} / B_{y}\right) \mathrm{K}
$$

where $\mathrm{CI}_{x}$ is the competitive index of the target weed species $X, A_{x}$ is the measured variable (TDM, weed volume, or soybean yield loss) associated with target $X, B_{y}$ is the measured variable of the most competitive weed, and $K$ is a constant with a value of 10 . The constant $\mathrm{K}=10$ provides a common scale to calculate CI values that range from 0.01 to 10 and can be used to compare competitiveness among weed species. Common sunflower had the greatest TDM and volume, and reduced soybean yield loss the most when it emerged with soybean in $76-\mathrm{cm}$ rows compared to all other weed species. Thus, common sunflower was considered the most competitive weed species (e.g., $B_{y}$ ) to calculate all other CI values in this study.

\section{Results and Discussion}

\section{Weed Dry Matter Production}

Weed dry matter production was influenced by location $(P<0.05)$; therefore, Lincoln and Concord data were analyzed separately, but years were not different at Concord. Location differences can be attributed to rainfall amount and periodicity (Table 2 ). Lincoln received more timely rainfall during weed establishment and vegetative growth compared to Concord. In general, weed species produced higher TDM plant ${ }^{-1}$ at Lincoln than at Concord. At both locations, weed species from the first and second planting dates emerged at soybean VE and V1 stages, respectively (Table 1 ). Weed species seeded at the third planting date did not emerge at any of the two locations and years as a result of dry weather conditions (e.g., low rainfall and high temperature).

At Concord, TDM production was not significantly dif-

TABLE 2. Monthly rainfall, mean daily temperature, and their 30-yr averages in Concord, NE, during the 2002 and 2003 growing seasons

\begin{tabular}{|c|c|c|c|c|c|c|c|c|c|c|}
\hline \multirow[b]{3}{*}{ Month } & \multicolumn{5}{|c|}{ Rainfall } & \multicolumn{5}{|c|}{ Temperature } \\
\hline & \multicolumn{3}{|c|}{ Concord } & \multicolumn{2}{|c|}{ Lincoln } & \multicolumn{3}{|c|}{ Concord } & \multicolumn{2}{|c|}{ Lincoln } \\
\hline & 2002 & 2003 & 30 -yr average & 2003 & 30-yr average & 2002 & 2003 & 30 -yr average & 2003 & $30-y r$ average \\
\hline & & & $\mathrm{mm}$ & 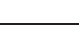 & 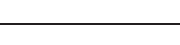 & & . & $-\mathrm{C}-$ & - & 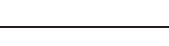 \\
\hline May & 68 & 107 & 98 & 68 & 107 & 13 & 14 & 16 & 16 & 17 \\
\hline June & 66 & 162 & 106 & 166 & 99 & 24 & 20 & 22 & 21 & 23 \\
\hline July & 47 & 63 & 79 & 26 & 91 & 26 & 24 & 24 & 27 & 25 \\
\hline August & 148 & 22 & 74 & 32 & 76 & 22 & 24 & 22 & 26 & 23 \\
\hline September & 14 & 173 & 67 & 97 & 84 & 18 & 17 & 17 & 17 & 18 \\
\hline Total & 343 & 527 & 424 & 389 & 457 & & & & & \\
\hline
\end{tabular}
and in Lincoln, NE, during the 2003 growing season. 

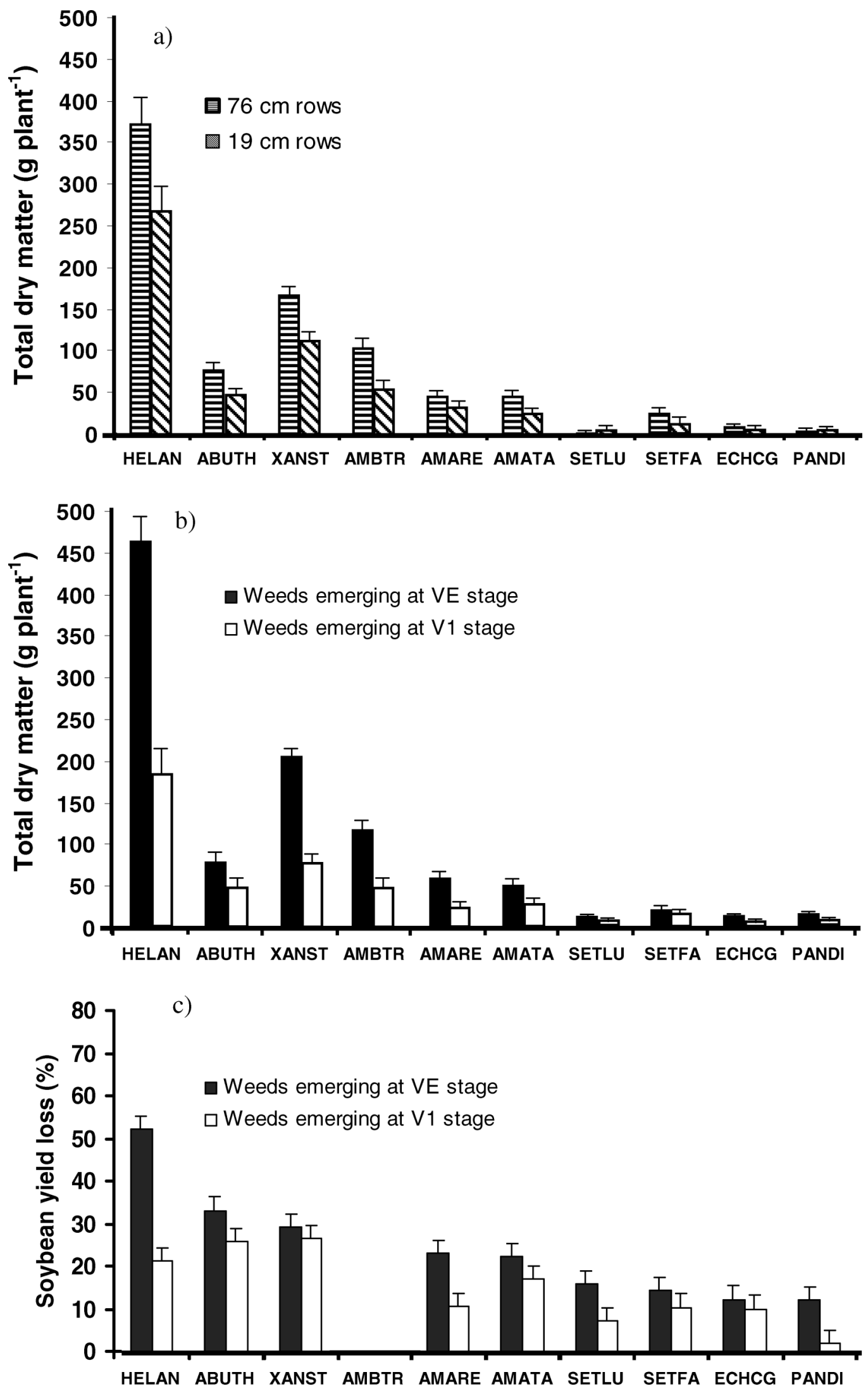

Figure 2. Weed species (WSSA-approved letter code for weed names) total dry matter (g plant ${ }^{-1}$ ) at Concord, NE (averaged over 2002 and 2003 ) as influenced by (a) soybean row spacing, (b) time of weed emergence, and soybean yield loss at Concord (averaged over 2002 and 2003) as influenced by time of weed emergence. Means and standard error bars based on least significant means (lsmeans) $(\mathrm{P}<0.05)$. 

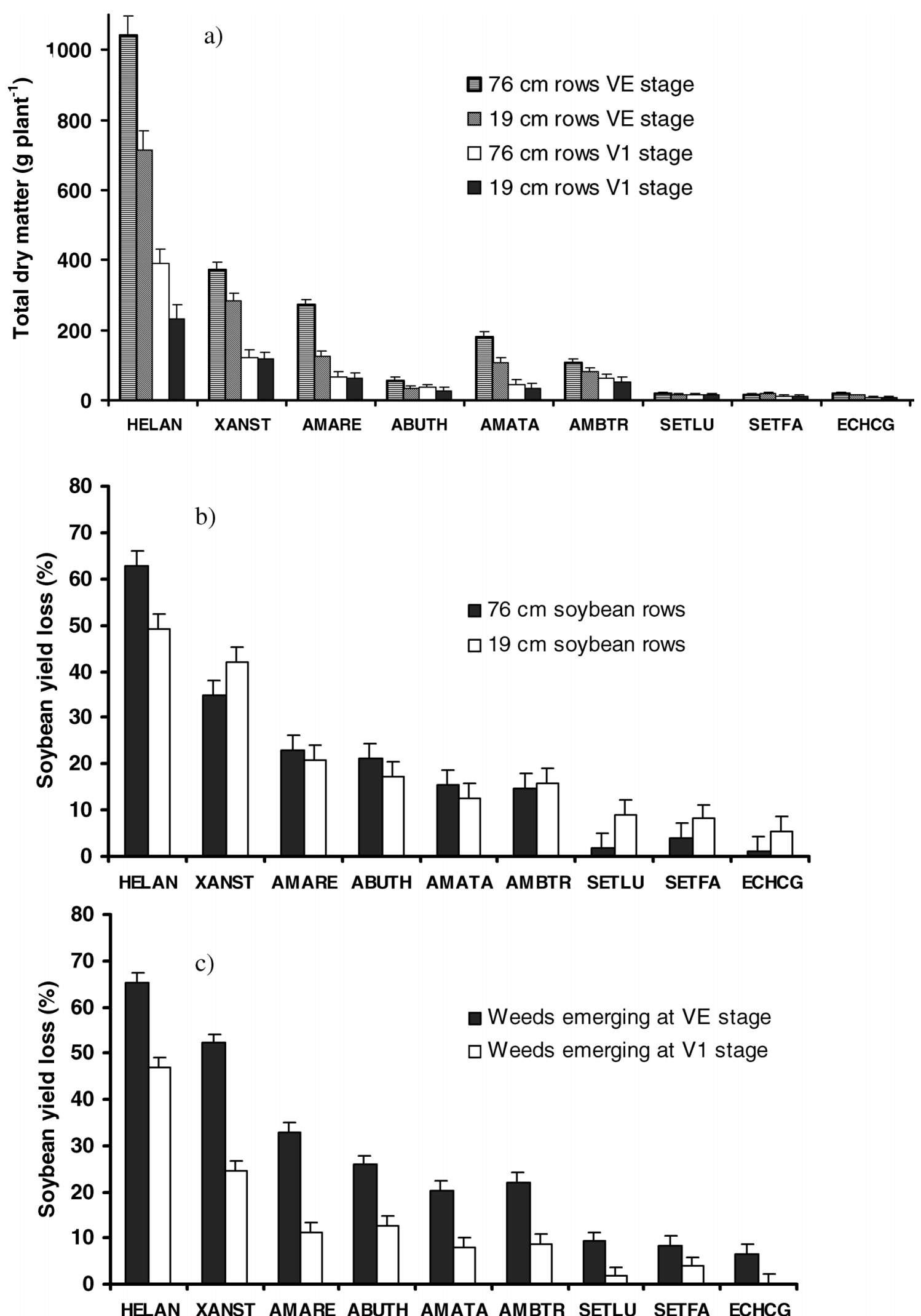

FIgURE 3. Weed species (WSSA-approved letter code for weed names): (a) total dry matter $\left(\mathrm{g}\right.$ plant $^{-1}$ ) as influenced by three-way interaction between soybean row spacing, time of weed emergence, and weed species; soybean yield loss (\%) as influenced by (b) soybean row spacing and (c) time of weed emergence at Lincoln, NE, in 2003. Means and standard error bars based on least significant means (lsmeans) $(\mathrm{P}<0.05)$. 
TABLE 3. Weed species plant volume as influenced by soybean row spacing (76- and 19-cm rows), time of weed emergence (emergence [VE] and first trifoliate leaf [V1] crop stages), and weed species at Concord, NE (averaged over 2002 and 2003) and Lincoln, NE (2003).

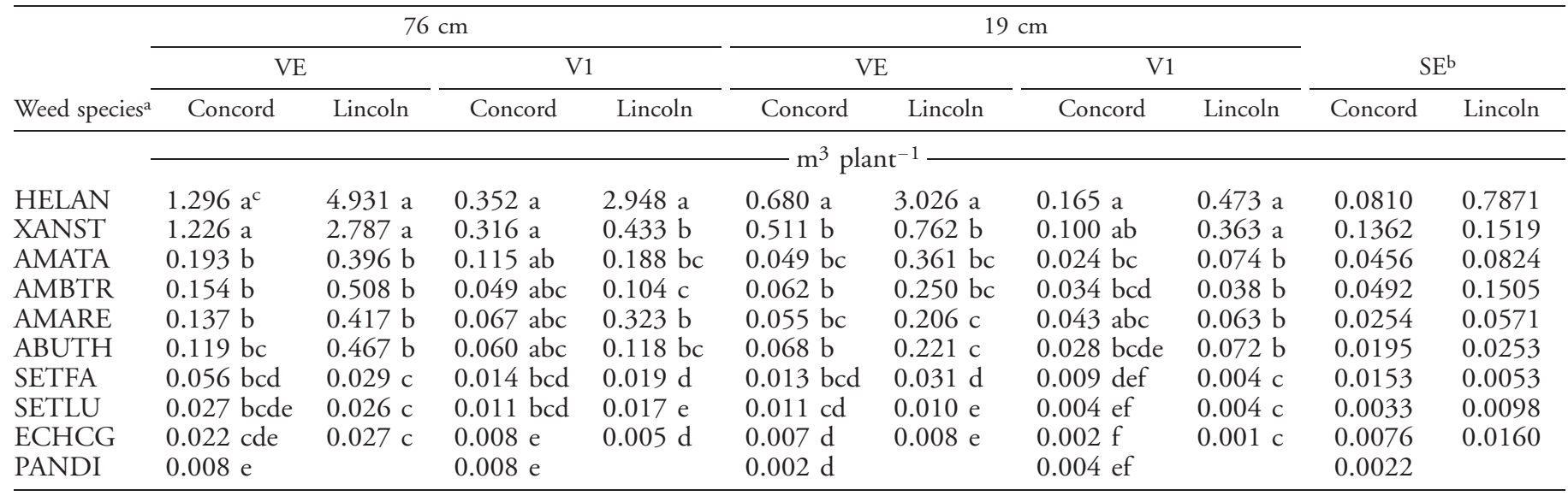

a WSSA-approved letter code for weed names.

${ }^{\mathrm{b}}$ Means and standard errors (SE) for each weed species, based on least squares means and $\mathrm{P}<0.05$.

${ }^{c}$ Within a column, the same letter indicates that the weed volume is not significantly different based on a multiple range $t$ test at $\mathrm{P}<0.05$.

ferent among years; therefore, data were combined. There was a two-way interaction between soybean row spacing and weed species and between weed emergence time and weed species $(\mathrm{P}<0.05)$; therefore, weed species data were presented separately for each row spacing and emergence time. Most weed species grown in $19-\mathrm{cm}$ rows produced less TDM than in 76-cm rows (Figure 2a). Common sunflower produced 375 and $275 \mathrm{~g} \mathrm{plant}^{-1}$ of TDM when grown in $76-$ and 19-cm soybean rows, respectively. Overall, grass weed species produced the least amount of TDM (Figure 2a).

Weed emergence time affected weed growth at Concord. Weeds produced less TDM when emerging at the V1 soybean stage than earlier-emerging ones at the VE stage. For example, common waterhemp produced $50 \mathrm{~g} \mathrm{plant}^{-1}$ when emerging early compared to $25 \mathrm{~g} \mathrm{plant}^{-1}$ emerging later (Figure 2b). In general, broadleaf weed species were impacted more by relative emergence time than were grass weed species.

At Lincoln, there was a three-way interaction between soybean row spacing, weed emergence time, and weed species $(\mathrm{P}<0.05)$; therefore, weed species data were presented separately for each row spacing and emergence time. Generally, weed species grown in $76-\mathrm{cm}$ wide rows produced more TDM plant ${ }^{-1}$ than in $19-\mathrm{cm}$ rows (Figure 3a). Also, weed species that emerged with the crop produced more TDM plant ${ }^{-1}$ than later-emerging weeds (Figure 3a).

\section{Weed Volume}

In general, results based on weed volume followed the same trend as those of TDM production. Because weed volume varied among locations, data were analyzed separately for each site $(P<0.05)$. Generally, weeds grown at Concord had lower volume than those from Lincoln (Table 3). Common sunflower produced greater plant volume at Lincoln than Concord. This difference has been observed in the past (A. R. Martin, unpublished data) and may be due to the higher temperatures in Lincoln than in Concord.

Because weed volume data at Concord were not significantly different between years, data were combined. There was a three-way interaction between soybean row spacing, weed emergence time, and weed species $(P<0.05)$; therefore, weed species data were presented separately for each row spacing and emergence time. Weeds grown in $76-\mathrm{cm}$ soybean rows produced more volume than those in $19-\mathrm{cm}$ rows for each emergence cohort (Table 3). However, soybean row spacing had more impact on earlier- than on lateremerging weeds. This is likely a result of soybean canopy closure timing. In general, soybean canopy closure occurred about $20 \mathrm{~d}$ later in $76-\mathrm{cm}$ than in $19-\mathrm{cm}$ rows, providing a longer shade-free environment. This provided a competitive advantage to weeds emerging at the first emergence date (VE). Broadleaf weeds generally produced greater plant volume than grass species (Table 3). However, that was not the case for all species. Velvetleaf and giant foxtail plant volumes did not differ in any treatment.

At Lincoln, plant volume data had a three-way interaction between soybean row spacing, weed emergence time, and weed species $(\mathrm{P}<0.05)$; therefore, weeds species data are presented separately for each row spacing and emergence time (Table 3). Common waterhemp, common sunflower, redroot pigweed, and giant foxtail produced more plant volume in $76-\mathrm{cm}$ than in $19-\mathrm{cm}$ soybean rows. Plant volume was affected similarly to weed emergence time as it did at Concord.

\section{Soybean Yield Loss}

Soybean yield loss varied across locations; therefore, data were presented separately for each site $(\mathrm{P}<0.05)$. At Concord, there were no effects of year or row spacing, but there was an interaction between weed emergence time and weed species $(\mathrm{P}<0.05)$. Generally, weeds emerging with soybean caused greater yield reduction than those emerging at the V1 crop stage. For instance, soybean yield loss was 52 and $21 \%$ when common sunflower emerged at the VE and V1 crop stages, respectively (Figure 2c).

At Lincoln, soybean yield loss was dependent upon row spacing as well as each weed emergence time $(\mathrm{P}<0.05)$. Generally, weeds caused greater soybean yield losses when grown in 76 - than in 19-cm soybean rows. The difference 
between yield losses in 76- vs. 19-cm rows was 29 and 31\% for common sunflower and velvetleaf, respectively (Figure $3 \mathrm{~b})$. However, common cocklebur, giant ragweed, and grass species affected soybean yield loss similarly in both row spacings. This may be explained by giant ragweed and common cocklebur apparent tolerance to reduced light (Regnier and Stoller 1989; Webster et al. 1994). Webster et al. (1994) reported that giant ragweed was able to compete for light by placing leaves both within and above the soybean canopy. Common cocklebur has been described as a species that does not grow taller than the soybean canopy until much later in the season (Regnier and Stoller 1989). They suggested that common cocklebur can branch extensively, shading lower soybean leaves during early- and mid-season. Contrary to common cocklebur that exploits both full light (above crop canopy) and shaded environment (within crop canopy), velvetleaf was described as a species that prefers to use light by placing most of its leaves above the soybean canopy (Regnier and Harrison 1993). This suggests that common cocklebur and giant ragweed can be as competitive in 19as in 76- $\mathrm{cm}$ soybean rows compared to the other broadleaf weeds, such as velvetleaf, which alters its canopy upwards to shade the soybean crop. Additionally, weed emergence time affected soybean yield loss similar to that observed at Concord (Figure 3c).

At both locations, broadleaf weeds caused greater yield reduction than grasses. For instance, at Concord, common sunflower, velvetleaf, common cocklebur, redroot pigweed, and common waterhemp caused 52, 33, 29, 23, and $23 \%$ yield loss when they emerged with the crop, respectively, compared to yellow foxtail, giant foxtail, barnyardgrass, and fall panicum, which caused 16, 15, 13, and 13\% yield loss, respectively (Figure 2c). We suggest that lower yield losses caused by grasses are likely a result of the low grass density used in this study. Although the yield losses presented in this paper provided a good indication of weed competitiveness when compared among species grown at the same density, it is important to note that under high grass pressure, crop yield loss can be as high as the losses caused by most competitive broadleaf weed (S. Z. Knezevic, unpublished data).

\section{Competitive Indices Based on Measured Variables}

CI values were presented according to the significant effects of site, row spacing, or emergence time for each variable tested (TDM, weed volume, soybean yield loss). Generally, CI values were higher for most weeds grown in wider crop rows and for earlier weed emergence times (Tables 46). For example, CI values based on TDM for common sunflower, common cocklebur, and velvetleaf were 10, 4.53, and 2.08 in $76-\mathrm{cm}$ wide rows compared to $7.33,2.99$, and 1.27 in $19-\mathrm{cm}$ rows for each respective weed at Concord (Table 5). When the same species emerged at the VE stage in $76-\mathrm{cm}$ rows, CI values were $10,3.59$, and 0.54 compared to $3.74,1.17$, and 0.34 for emergence at the V1 stage, respectively, based on TDM. A similar response was observed for CI values based on soybean yield loss (Table 4) and volume (Table 6).

Broadleaf weeds were more competitive than grass weeds, which resulted in much higher CI values for broadleaf species. For instance, common sunflower had CI $=10$ based on TDM, volume, or yield loss; and common cocklebur had

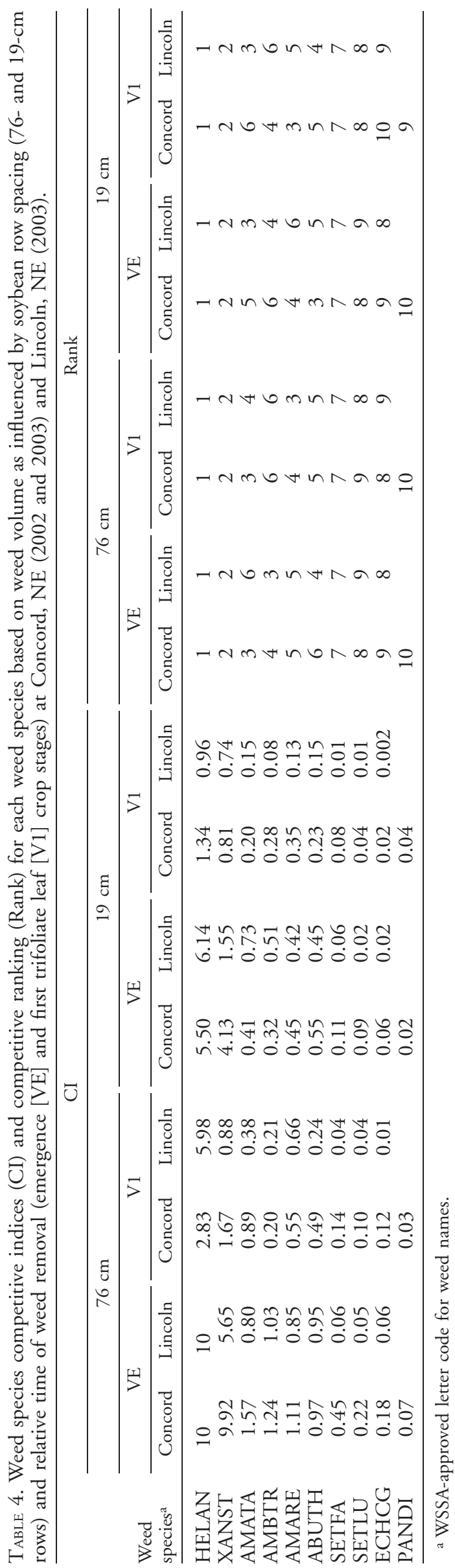


TABLE 5. Weed species competitive index (CI) and competitive ranking (Rank) for each weed species based on total dry matter ( $\mathrm{g}$ plant ${ }^{-1}$ ) as influenced by soybean row spacing (76- and 19-cm rows) and time of weed emergence (emergence [VE] and first trifoliate leaf [V1] crop stages) at Concord, NE (averaged over 2002 and 2003) and Lincoln, NE (2003).

\begin{tabular}{|c|c|c|c|c|c|c|c|c|c|c|c|c|c|c|c|c|}
\hline \multirow{4}{*}{$\begin{array}{l}\text { Weed } \\
\text { species }^{\mathrm{a}}\end{array}$} & \multicolumn{8}{|c|}{ CI } & \multicolumn{8}{|c|}{ Rank } \\
\hline & & & & & \multicolumn{4}{|c|}{ Lincoln } & & & & & \multicolumn{4}{|c|}{ Lincoln } \\
\hline & \multicolumn{4}{|c|}{ Concord } & \multicolumn{2}{|c|}{$76 \mathrm{~cm}$} & \multicolumn{2}{|c|}{$19 \mathrm{~cm}$} & \multicolumn{4}{|c|}{ Concord } & \multicolumn{2}{|c|}{$76 \mathrm{~cm}$} & \multicolumn{2}{|c|}{$19 \mathrm{~cm}$} \\
\hline & VE & V1 & $76 \mathrm{~cm}$ & $19 \mathrm{~cm}$ & VE & V1 & VE & V1 & VE & V1 & $76 \mathrm{~cm}$ & $19 \mathrm{~cm}$ & $\mathrm{VE}$ & $\mathrm{V} 1$ & VE & V1 \\
\hline HELAN & 10 & 4.03 & 10 & 7.33 & 10 & 3.74 & 6.88 & 2.22 & 1 & 1 & 1 & 1 & 1 & 1 & 1 & 1 \\
\hline XANST & 4.42 & 1.66 & 4.53 & 2.99 & 3.59 & 1.17 & 2.74 & 1.12 & 2 & 2 & 2 & 2 & 2 & 2 & 2 & 2 \\
\hline AMBTR & 2.54 & 1.02 & 2.81 & 1.59 & 1.02 & 0.59 & 0.76 & 0.5 & 3 & 3 & 3 & 3 & 5 & 4 & 5 & 4 \\
\hline ABUTH & 1.71 & 1 & 2.08 & 1.27 & 0.54 & 0.34 & 0.31 & 0.25 & 4 & 4 & 4 & 4 & 6 & 6 & 6 & 6 \\
\hline AMATA & 1.09 & 0.54 & 1.3 & 0.72 & 1.74 & 0.44 & 1.04 & 0.33 & 6 & 6 & 5 & 6 & 4 & 5 & 4 & 5 \\
\hline AMARE & 1.23 & 0.56 & 1.29 & 0.93 & 2.62 & 0.64 & 1.22 & 0.61 & 5 & 5 & 6 & 5 & 3 & 3 & 3 & 3 \\
\hline SETFA & 0.41 & 0.37 & 0.61 & 0.36 & 0.16 & 0.11 & 0.18 & 0.1 & 7 & 7 & 7 & 7 & 9 & 8 & 7 & 8 \\
\hline PANDI & 0.29 & 0.12 & 0.32 & 0.18 & & & & & 8 & 9 & 8 & 10 & & & & \\
\hline ECHCG & 0.29 & 0.16 & 0.32 & 0.23 & 0.17 & 0.07 & 0.13 & 0.07 & 9 & 8 & 9 & 8 & 7 & 9 & 9 & 9 \\
\hline SETLU & 0.21 & 0.12 & 0.2 & 0.21 & 0.17 & 0.13 & 0.15 & 0.14 & 10 & 10 & 10 & 9 & 8 & 7 & 8 & 7 \\
\hline
\end{tabular}

a WSSA-approved letter code for weed names.

$\mathrm{CI}=3.6$ based on TDM, CI $=5.7$ based on volume, and $\mathrm{CI}=5.5$ based on yield loss in $76-\mathrm{cm}$ rows and emerging with the crop at Lincoln compared to many grass species whose CI values ranged from 0.01 to 3.1 across all measured variables (Tables 4-6).

There were also inconsistent results in CI values depending on what variable CI calculations were based, which also resulted in differential weed ranking (Tables 4-6). For example, in some cases CI based on volume were larger for weeds grown in 19- than 76-cm rows, and for later-emerging weeds compared to early-emerging ones, which was contrary to the CIs based on TDM and yield loss. This indicated that the CI values based on plant volume were the most inconsistent and possibly the least reliable. For instance, using CI based on volume, redroot pigweed was more competitive in narrow than in wide rows, which contradicted the CI values based on TDM and yield loss. Also, early-emerging common cocklebur in $76-\mathrm{cm}$ rows had a CI $=9.9$ at Concord based on plant volume compared to CI $=4.4$ based on TDM. The difference in CI values based on plant volume was likely a result of the method used to calculate plant volume for each weed species. Equation 1 assumes a cylindrical volume for every weed species; however, not all weed species have a cylindrical shape. Therefore, we suggest that future studies of plant volumes should use equations that are designed to account for respective plant shapes. For example, some species have a canopy in the shape of a cylinder, while others are "cone"- or "inverted cone"-shaped. Further studies are needed to test such a hypothesis.

Of the three plant variables tested, our data also suggested that the CI values based on soybean yield loss were the least variable. Therefore, we suggest that the yield loss parameter would be the most suitable parameter for quantifying weed species competitiveness in soybean. Preventing crop yield loss is of most significance to practitioners and a main reason for making weed management decisions.

Because of the variability in CI values between the two sites, we suggest that there is a need for further refinement of the CI concept for use with DSSs. A multi-state experiment may provide additional information about the potential magnitude of the site-specific variability that can influence CI values. Also, the CI values presented in this paper must be tested with current (or future) DSS computer pack-

TABLE 6. Weed species competitive index (CI) and competitive ranking (Rank) for each weed species based on soybean yield loss (\%) as influenced by relative time of weed emergence (emergence [VE] and first trifoliate leaf [V1] crop stages) at Concord, NE (averaged over 2002 and 2003) and at Lincoln, NE (2003), and soybean row spacing (76- and 19-cm rows) at Lincoln.

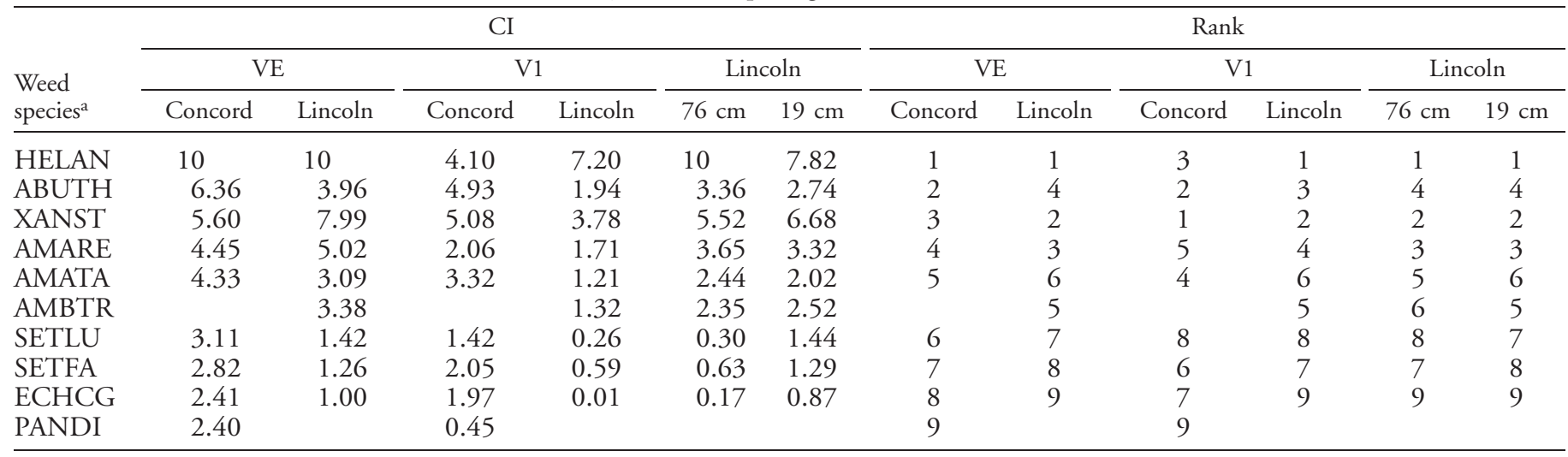

a WSSA-approved letter code for weed names. 
ages. For example, the CI values presented in this paper may improve performance of the WeedSOFT program by replacing current CIs, which are primarily based on expert opinion, with the "new" CIs from this multi-species study. Further evaluation of WeedSOFT is needed to test such a hypothesis.

Despite the variability in CI values between the two sites, the CI values and weed rankings presented in this paper can be useful to both practitioners and academics. Practitioners can use our CI data as a general rule of thumb for comparing competitive ability of weed species as part of their decision-making process for weed management. For example, knowing that there is a fivefold difference in competitive ability between a weed with $\mathrm{CI}=10$ and a weed with CI $=2$ can be very useful in making plans for weed control options. This can result in less extensive management options for less competitive weeds, which usually results in economic savings. Academics can use such information as a teaching tool for comparing weed species, both in a regular academic setting or extension activities. Perhaps students would like to know if five plants of a weed with $\mathrm{CI}=2$ would have a similar competitive ability as one plant with $\mathrm{CI}=10$. This provides a simple visual tool for comparison among weed species as part of an effective learning process.

\section{Acknowledgments}

Many thanks to Jon Scott, Ray Brentlinger, Jess Spotanski, Kevin Horky, Travis Gustafson, and many summer helpers for assisting with plot maintenance and treatment implementation. Published as University of Nebraska Agricultural Research Division Journal Series Number 14817.

\section{Literature Cited}

Bauer, T. A., D. A. Mortensen, G. A. Wicks, T. A. Hayden, and A. R. Martin. 1991. Environmental variability associated with economic thresholds for soybeans. Weed Sci. 39:564-569.

Chikoye, D., S. F. Weise, and C. J. Swanton. 1995. Influence of common ragweed (Ambrosia artemisiifolia) time of emergence and density on white bean (Phaseolus vulgaris). Weed Sci. 43:375-380.

Coble, H. D. and D. A. Mortensen. 1992. The threshold concept and its application to weed science. Weed Technol. 6:191-195.

Cousens, R., L. G. Firbank, A. M. Mortimer, and R.G.R. Smith. 1988 Variability in the relationship between crop yield and weed density for winter wheat and Bromus sterilis. J. Appl. Ecol. 25:1033-1044.

Evans, S. P., S. Z. Knezevic, J. L. Lindquist, C. A. Shapiro, and E. E. Blankenship. 2003. Nitrogen application influences the critical period for weed control in corn. Weed Sci. 51:408-417.

Forcella, F., R. P. King, S. M. Swinton, D. D. Buhler, and J. L. Gunsolus. 1996. Multi-year validation of a decision aid for integrated weed management in row crops. Weed Sci. 44:650-661.

Gunther, P., W. Pestemer, T. K. James, and A. Rahman. 1993. Testing the German herbicide advisory system HERBASYS under different edaph- ic and climatic conditions in New Zealand. Pages 777-784 in 8th EWRS Symposium, Quantitative Approaches in Weed and Herbicide Research and Their Practical Applications. Braunschweig, Germany: European Weed Research Society.

Knezevic, S. Z., S. P. Evans, E. E. Blankenship, R. C. van Acker, and J. L. Lindquist. 2002. Critical period for weed control: the concept and data analysis. Weed Sci. 50:773-786.

Knezevic, S. Z., S. P. Evans, and M. Mainz. 2003. Row spacing influences the critical timing for weed removal in soybean (Glycine max). Weed Technol. 17:666-673.

Knezevic, S. Z., M. J. Horak, and R. L. Vanderlip. 1997. Relative time of redroot pigweed (Amaranthus retroflexus L.) emergence is critical in pigweed-sorghum [Sorghum bicolor (L.) Moench] competition. Weed Sci. 45:502-508.

Knezevic, S. Z., S. F. Weise, and C. J. Swanton. 1995. Comparison of empirical models depicting density of Amaranthus retroflexus L. and relative leaf area as predictors of yield loss in maize. Weed Res. 35: 207-214.

Lindquist, J. L., D. A. Mortensen, P. Westra, et al. 1999. Stability of corn (Zea mays)-foxtail (Setaria spp.) interference relationships. Weed Sci. 47:195-200.

Lotz, L.A.P., S. Christensen, D. Cloutier, et al. 1996. Prediction of the competitive effects of weeds on crop yields based on the relative leaf area of weeds. Weed Res. 36:93-101.

Martin, A. R., J. L. Haffield, D. D. Buhler, and B. A. Stewart. 1997. Models for weed management (in-field management tools). Pages 6368 in Weed Biology, Soil Management and Weed Management. Chelsea, MI: Ann Arbor Press.

Medd, R. W. and S. Pandey. 1993. Compelling grounds for controlling seed production in Avena species (wild oats). Pages 769-776 in 8th EWRS Symposium, Quantitative Approaches in Weed and Herbicide Research and Their Practical Applications. Braunschweig, Germany: European Weed Research Society.

Neeser, C., J. A. Dille, G. Krishnan, D. A. Mortensen, J. T. Rawlinson, A. R. Martin, and L. B. Bills. 2004. WeedSOFT ${ }^{\circledR}$ : a weed management decision support system. Weed Sci. 52:115-122.

Regnier, E. E. and S. K. Harrison. 1993. Compensatory responses of common cocklebur (Xanthium strumarium) and velvetleaf (Abutilon theophrasti) to partial shading. Weed Sci. 41:541-547.

Regnier, E. E. and E. W. Stoller. 1989. The effects of soybean (Glycine max) interference on the canopy architecture of common cocklebur (Xanthium strumarium), jimsonweed (Datura stramonium), and velvetleaf (Abutilon theophrasti). Weed Sci. 37:187-195.

Ritchie, S. W., J. J. Hanway, and G. O. Benson. 1993. How a Soybean Plant Develops. Special Rep. 53. Ames, IA: Iowa State University. $20 \mathrm{p}$.

[SAS] Statistical Analysis Systems. 1999. SAS OnLine Doc. Version 8. Cary, NC: Statistical Analysis Systems Institute.

Schweizer, E., L. Wiles, D. Lybecker, and P. Westra. 1994. Bioeconomic Modeling for Weed Management Decisions in Crops. Great Plains Agriculture Council Bull. 150, pp. 135-141.

Stigliani, L. and C. Resina. 1993. SELOMA: expert system for weed management in herbicide-intensive crops. Weed Technol. 7:550-559.

Webster, T. M., M. M. Loux, E. E. Regnier, and S. K. Harrison. 1994. Giant ragweed (Ambrosia trifida) canopy architecture and interference studies in soybean (Glycine max). Weed Technol. 8:559-564.

Wilkerson, G. G., S. A. Modena, and H. D. Coble. 1991. HERB: decision model for postemergence weed control in soybean. Agron. J. 83:413417.

Received February 3, 2005, and approved August 17, 2005. 